Dušanka Točanac

Univerzitet u Novom Sadu

Filozofski fakultet
удК 371.3::811.133.1(497.11)

DOI https://doi.org/10.18485/zivjez.2017.37.1.6

Прегледни научни рад

\title{
NAŠE ISKUSTVO O RANOJ NASTAVI STRANOG JEZIKA U ŠKOLSKOM SISTEMU
}

Projekti Saveta Evrope s kraja prošlog veka podstakli su velika interesovanja za učenje evropskih jezika u cilju podizanja nivoa komunikacionih sposobnosti građana, njihovog zbližavanja i razvijanja svesti o zajedništvu. U tom smislu u Evropi je stasalo jedno novo shvatanje o jezičkoj politici tako da se u današnje vreme učenje stranih jezika spustilo na rani životni nivo, na sam početak školskog obrazovanja. U metodologiji učenja jezika stvoren je jedan novi termin koji sam po sebi mnogo znači: nastava jezika na ranom uzrastu.

Naše iskustvo o nastavi stranog jezika na ranom školskom uzrastu stečeno je tokom druge polovine prošlog veka putem organizovanih eksperimenata na kojima se već dosta davno grade sadašnji nastavni modeli za strane jezike.

U ovom referatu je, dakle, reč o osnivanju dvojezične nastave u Osnovnoj školi Vladislav Ribnikar i eksperimentu koji je u organizaciji Prosvetno-pedagoškog zavoda grada Beograda sproveden u nastavi četiri strana jezika od 1968. do 1977. godine.

Ključne reči: francuski jezik, nastava/učenje na ranom uzrastu, OŠ Vladislav Ribnikar.

\section{Kako smo počeli}

Tokom pedesetih i šezdesetih godina prošlog veka, dva strana jezika, francuski i ruski, našla su se u nastavnom planu i programu u ravni ravnopravnih predmeta sa engleskim i nemačkim. Ova dva poslednja jezika imala su zaista u ono vreme nisku zastupljenost u odnosu na ruski koji je počev od pedesete godine izgubio status obaveznog predmeta ali se predavao u nekim krajevima i dalje u mnogim školama i na svim nivoima. S druge strane, u Srbiji je i fran- 
cuski, imajući u vidu tradiciju, bio visoko zastupljen. Pokušaj da se postigne željena ravnopravnost u zastupljenosti četiri jezika propisana školskim programima i uputstvima koja su ih pratila (1957, 1959, 1963), suprotno nameri, doveo je do radikalnog smanjenja učenika francuskog i ruskog jezika, mada je u primeni, statistički gledano, početkom šezdesetih godina ruski jezik i pored represivnih mera i dalje bio prisutan u visokom procentu, imajući u vidu da je prethodna pokrivenost ovim jezikom bila stopostotna, dok je u toj nameri za ravnopravnim tretmanom jezika francuski jezik takoreći nestao iz mnogih škola širom Srbije, sa tendencijom daljeg nestajanja. Učenje ovog jezika se svelo na mali postotak, nemački se nije znatno povećao na statističkoj listi, ruski je i dalje ostao visoko zastupljen, a za engleski nije bilo dovoljno kadra. Nastali disbalans u zastupljenosti stranih jezika nikada nije ispravljen: vremenom je engleski, kao i svuda u svetu, postao najzastupljeniji strani jezik, dok su se iza njega ređali ruski, nemački i francuski ${ }^{1}$ zavisno od regiona i kadrovskih mogućnosti. Ne može se reći da je ova situacija bila mirno prihvaćena u krugovima kompetentnih institucija i pedagoških stručnjaka. U to doba mogle su se čuti ili pročitati mnoge diskusije o potrebi ravnomernije zastupljenosti stranih jezika u našim školama, kao i mnoge reakcije strukovnih udruženja i drugih asocijacija. Jedna ozbiljna diskusija o ovom problemu, s ciljem da se održi u razumnoj meri prisustvo francuskog jezika u našim školama a samim tim i prisustvo ovog jezika u našoj kulturi, povela se ranih šezdesetih godina u Društvu za kulturnu saradnju Jugoslavija Francuska, koje je u svom programu, pored negovanja i održavanja kulturnih veza, imalo za zadatak i brigu o učenju i širenju francuskog jezika ${ }^{2} u$ našoj sredini. Ozbiljnost problema je rasla iz godine $u$ godinu. To je podstaklo ugledne članove Društva (predsednika Du-

1 U sadašnje vreme ovo nisu jedini jezici koji su zastupljeni u našim školama. Italijanski i španski imaju ravnopravni status sa prethodna četiri, a mnoge škole organizuju fakultativnu nastavu drugih jezika, kao na primer grčkog, japanskog, kineskog itd.

2 Koliko me sećanje služi, već negde sredinom pedesetih godina, biće da je to bilo 1954. godine, Društvo za kulturnu saradnju organizovalo je časove francuskog jezika. Kao studenti francuskog jezika,1957. godine moja drugarica Mira Kun i ja bile smo jedine učenice na časovima profesora Miće Stojiljkovića, koji je istovremeno vršio dužnost sekretara, a posećivale smo i časove konverzacije profesora Darinke Marodić i Ružice Dimitrijević. 
NAŠE ISKUSTVO O RANOJ NASTAVI STRANOG JEZIKA U ŠKOLSKOM SISTEMU

šana Matića, sekretara Miru Alečković, a tu su bili i Kiril Svinarski i profesor Mila Maksimović) da se ozbiljno zauzmu kod odgovornih institucija u pravcu održavanja francuskog jezika. Rezultat takve angažovnosti jeste uvođenje intenzivne eksperimentalne nastave francuskog jezika u prvi razred 1966. godine, dakle u uzrastu od sedam godina, u Osnovnoj školi „Slobodan Princip Seljo“ ${ }^{\text {3. }} 0$ nastavi u eksperimentalnom projektu ${ }^{4}$, izgleda prvom u našoj zemlji ovog tipa, u školi „Slobodan Princip Seljo“ govoriće ovde neko ko je to izbliza pratio. Ono što je za moje izlaganje značajno jeste to što ova škola, koja, kako je poznato, radi i dalje u istom statusu, beleži datum legitimnog i administrativnog početka nastave stranog jezika u školskom kontekstu na uzrastu od sedam godina. Kasnije nazvana „Vladislav Ribnikar“, „Slobodan Princip Seljo“ je škola koja u razvoju nastave stranog jezika predstavlja onaj plamičak koji će u narednim godinama podgrejati shvatanje javnosti i svest roditelja o potrebi za učenjem stranog jezika od samog početnog obrazovanja dece. Posle uspeha koji je bio očigledan i kojeg smo svi bili svesni, učvrstila se i u našoj jezičkoj politici misao o potrebi da se uvede strani jezik kao ravnopravni predmet, ako ne i predmet sa više posvećenosti nego li prema drugim predmetima koji su se učili u prvom razredu osnovne škole. Nije više bilo ni teško ni uzaludno govoriti o ranom učenju stranog jezika. Naravno, bilo je svima jasno da se strani jezik nije mogao predavati u svim školama po modelu koji je zastupljen u pomenutoj školi. Bilo je potrebno pronaći neki novi modalitet, koji može biti finansijski i kadrovski održiv, pogodniji za masovniju primenu. Ni metod koji se primenjivao u nastavi ove škole nije mogao da bude primenljiv. Objektivno, nedostajalo je iskustvo ${ }^{5}$, a nije se

3 Istovremeno i u Osnovnoj školi „Isidora Sekulić“; ova škola je, međutim, ubrzo prebačena na sistem učenja francuskog jezika po modelu Prosvetno-pedagoškog zavoda, o čemu će biti reči u daljem izlaganju.

4 U Srbiji nije bilo iskustava sa takvim vidom nastave, niti pripremljenog pedagoškog materijala. Shvatajući značaj ovog poduhvata, Francuski kulturni centar je doveo dva učitelja iz Francuske, koji su pored ovdašnjih nastavnika bili angažovani u nastavi i uspostavljali metodologiju pristupa i nastavnih postupaka

5 U to vreme, jedini dostupan rad koji se bavio istraživanjem sposobnosti dece od sedam godina za učenje stranog jezika bio je rad Milje Stošić koja je u Institutu za strane jezike u Jovanovoj eksperimentalno ispitivala sposobnost dece od sedam i devet godina za učenje jezika (v. napomenu 10). 
moglo osloniti na iskustva drugih, pogotovo ne na ona stečena na raznim kursevima jezika za decu, kakvih je u velikom broju bilo u Beogradu. Ipak, na inicijativu školskih inspektora za strane jezike i uz svesrdnu pomoć univerzitetskih profesora, u drugom polugodištu školske 1967/68 Prosvetno-pedagoški zavod Beograda pokreće jedan novi eksperiment.

Za prvu eksperimentalnu godinu novog projekta bilo je angažovano dvanaest beogradskih osnovnih škola, po tri škole za svaki jezik, (a svake sledeće školske godine broj će se uvećavati za još toliko) i po tri nastavnika jezika u čiju se spremnost za takav poduhvat verovalo ${ }^{6}$. I tako je nastava na ranom uzrastu, uglavnom u beogradskim školama (zbog čega će ceo ovaj projekat ostati prepoznatljiv pod nazivom „beogradski model") pustila korene u shvatanju neophodnosti učenja stranog jezika u ranom uzrastu, a 2003. godine taj nastavni model služiće za osnovu opštem nastavnom planu za strane jezike koji će postati obavezan na celoj teritoriji Srbije.

\section{Projekt Saveta Evrope}

Programski pristup nastavi stranih jezika na ranom uzrastu široko je aktuelizovan krajem prošlog veka projektom Saveta Evrope "Language Learning for European Citizenship" i velikim brojem drugih dokumenata koji su proizašli iz ovog projekta ${ }^{7}$. U inicijalnom stadijumu projekta učenje na ranom uzrastu postavljeno je kao primarna tema s obzirom na to da je već Preporukama (Recommandations 12) iz prethodnog Projekta (Langues vivantes) postavljen cilj da se za građane Evrope, posebno one u Evropskoj uniji, podigne nivo međusobne komunikacije. Imajući u vidu brojnost evropskih jezika, nameru da se promovišu i oni jezici kojima se služi manji broj evropskih zajednica, kao i da je učenje svakog jezika, čak i ma-

$\overline{6}$ Ovaj eksperimenat završen je 1977-78. godine; ukupno 36 škola bilo je angažovano po jednom jeziku, što zači da je eksperimenat obuhvatao ukupno 144 beogradske škole, ili 4-5 hiljada učenika.

7 Résolution du Conseil du 16 décembre 1997 concernant l’apprentissage précoce des langues. 
NAŠE ISKUSTVO O RANOJ NASTAVI STRANOG JEZIKA U ŠKOLSKOM SISTEMU

ternjeg, proces koji prati ceo život svakog pojedinca, države-članice SE istakle su potrebu da se učenju stranih jezika dâ više prostora u školskom sistemu. U skladu s tim dogovorile su se da, prema svojim mogućnostima, unesu u školske programe ovu činjenicu i spuste početak učenja stranih jezika koliko je moguće u odnosu na početak koji je zabeležen tada važećim nastavnim planom.

Te godine, 1988, kada su se u Strazburu saopštavali rezultati projekta Langues vivantes, utvrđivale potrebe evropske zajednice u domenu jezičkih istraživanja i određivale istraživačke teme za naredni projekat, iako samo kandidat za prijem u Savet Evrope, SFRJ je imala svoje predstavnike u direkciji za promociju evropskih jezika. Bilo je veliko iznenađenje za mnoge predstavnike zemalja članica, a bilo ih je tada 25 , da je naša zemlja u to vreme imala organizovanu nastavu četiri strana jezika u osnovnoj školi, dakle na ranom uzrastu, u jednom značajnom broju škola. Pri tom, za sobom je imala i završen projekt eksperimentalne nastave stranih jezika (engleski, francuski, nemački i ruski) od prvog do osmog razreda koji je pretočen kasnije i proširen na programsko učenje jezika u osnovnim školama od trećeg razreda, da bi definitivno bio spušten na prvi razred 2003. kao obavezni nastavni predmet. Godine 2007. strani jezik je uveden i u peti razred kao drugi strani jezik, izborni za školu, obavezan za učenike. Tako su u većini osnovnih škola krajem šezdesetih godina bila već zastupljena u programu dva strana jezika, a nije suvišno ponoviti i to da smo u našem pedagoškom iskustvu imali i celu školu od skoro dve hiljade učenika u kojoj se nastavni program realizovao dvojezično, na srpskom i na francuskom jeziku. Od velikog značaja je bila i činjenica da je dvojezični pristup nastavi u višenacionalnim sredinama širom cele SFRJ bio uobičajena forma pedagoškog rada. Uz to, treba istaći i posvećenost jugoslovenskih psiholingvista koji su svojim projektima o dečijem govoru u multinacionalnim sredinama bili poznati daleko van granica. Sve to doprinelo je da realizaciju projekta o ranom učenju stranih jezika i jezičkih pitanja u razvoju dece koja žive u oblastima u kojima se susreću različite kulture Direkcija za jezike SE, preciznije direktor projekta John Trim, dodeli Institutu za strane jezike Filozofskog fakulteta u Novom Sadu i, kao partneru u tom projektu, Velškom Uni- 
verzitetu u Karmartenu ${ }^{8}$. Tako je planiran workshop new style koji je imao zadatak da u radu prvog sastava sagleda ovu tematiku, definiše istraživačke zadatke čiji bi rezultati i zaključci bili saopšteni u radu drugog sastava. Zadatak je podeljen izmedju Velsa, Univerziteta u Karmartenu i SFRJ, Univerziteta u Novom Sadu. Septembra meseca 1991. godine održan je prvi workshop u Karmartenu. Prisustvovao je veliki broj naših predstavnika iz cele zemlje, u sećanju su mi prof. Ivan Ivić, prof. Melanija Mikeš, prof. Radmila Šević, prof. Lucija Čok, kao i desetak saradnika Melanije Mikeš koji su radili sa decom iz bilingvalnih vojvođanskih sredina. Određene su smernice rada, podeljeni su zadaci. Očekivalo se da će se rezultati saopštiti na sledećem sastanku u Novom Sadu. Međutim, politički događaji promenili su tok ovog projekta.

\section{3. Šta se podrazumeva pod ranim učenjem stranog ili drugog jezika?}

Učenje jezika na ranom uzrastu u reformisanim školskim programima prisutno je sada u svim zemljama Evrope ${ }^{9}$. Svest o generalnoj potrebi za znanjem više jezika nametnula je i shvatanje o neophodnosti učenja jezika. Početkom novog veka diskusija o učenju jezika intenzivno je zahvatila evropsko društvo koje je pokazalo spremnost i otvorenost za komunikaciju sa svojim sugrađanima. Tako je strani jezik, kao aktivnost, ušao u dečije vrtiće (predškolski nivo), uvrstio se kao punopravan predmet u početno obrazovanje (učenje jezika na ranom uzrastu), a u višejezičnim sredinama dobio sigurno mesto ne samo kao maternji jezik, već i kao jezik sredine ili okruženja, ali i kao strani jezik. Iz ovih razloga značenje termina

8 Iako je planiran kao projekat Velsa i SFRJ, odnosno Univerziteta u Karmartenu i Univerziteta u Novom Sadu, 1992. godine održan je samo prvi skup u Karmartenu u predviđenom sasatavu. Sticajem neprijatnih političkih događaja početkom devedesetih godina prošlog veka postignuti rezultati , u jednom drugom sastavu i sa drugačije obrađenim istraživačkim temama, predstavljeni su u Strazburu 1997. godine.

9 Videti iscrpne statističke podatke date u tekstu Eurostat 2012. godine Chiffres clés de l'enseignement des langues à l'école en Europe. OECD, PISQ Eurostat. 
NAŠE ISKUSTVO O RANOJ NASTAVI STRANOG JEZIKA U ŠKOLSKOM SISTEMU

„učenje stranog jezika na ranom uzrastu“ usložnjava se različitim vidovima nastave u kontekstu školskog programa, ali i vanškolskih institucija. Iako se u profesionalnim krugovima istraživanja jasno izdvajaju, tri oblasti u praksi se još uvek pokrivaju terminom „rano učenje" u zavisnosti od publike koja je cilj istraživanja, metode koja se primenjuje u nastavnom procesu i uslova u kojima se sprovodi nastava. U ovom svom izlaganju ja se uglavnom oslanjam na svoja znanja i iskustva koja proističu iz mog rada sa učenicima od prvog do osmog razreda osnovne škole u okviru projekta Prosvetno-pedagoškog zavoda u Beogradu ${ }^{10}$ koji se odnosi na nastavu stranih jezika. Shvatam da se granice između tri nastavna procesa ne mogu ograditi nikakavim tarabama, da upotrebim ovde izraz Melanije Mikeš koja je nesebično sebe dala u proučavanju dečijeg govora u višejezičnoj sredini, ipak, svaka oblast ima svoje specifičnosti koje utiču na definitivne ishode.

Da li je učenje jezika od ranih godina modni trend ili ozbiljna potreba u društvenim zajednicama? Da li se strani jezik može progovoriti i u kasnijem uzrastu, u doba adolescencije ili u doba potpunog odrastanja? Svakako da može, francuskim jezikom je govorio i moj deda kada se vratio preko Kajmakčalana zajedno sa svojim saborcima Francuzima. Potreba za komunikacijom sa bližnjima jeste životna potreba, a motivacija se najčešće crpi iz okolnosti u kojima se čovek nađe. Tačno je da se danas biraju i vrtići i škole zavisno od jezika koje nude učenicima, jer u ova današnja vremena, kada se o budućnosti razmišlja više nego o prošlosti, svaki roditelj ima viziju obrazovanja svoje dece. Zato je tačno i to da su mnogi roditelji nesrećni što nisu u finansijskoj situaciji da plate skupe predškolske kurseve svojoj deci. Stoga učenje na početnom stepenu obrazovanja koje se ostvaruje u osnovnim školama ima mnogo značaja jer predstavlja veliku potrebu za najšire društvene slojeve. Negde sam pročitala da se jezik, maternji, uči tokom celog života. Kad je strani jezik u pitanju, ovaj princip ima još veću važnost za uspeh, a kada su pored toga učeniku pružene bolje pogodnosti i duže vreme da

10 Eksperiment se odnosi na francuski jezik u Osnovnoj školi „Jovan Cvijić“ od 1968 do 1975. Isti eksperiment je izvodila Vera Ilijin Jankes u OŠ „Proleterskih brigada“ i Branka Jakovljević u osnovnoj školi u Surčinu. 
nauči drugi jezik pored svog maternjeg, onda je to sigurna dobit. Šta još nedostaje? Posvećenost učitelja i motivacija učenika da bi se realizovao postavljeni cilj.

\section{Deca kao subjekti u procesu nastave stranog jezika}

Pitanjem usvajanja stranog jezika na ranom uzrastu bave se lingvisti, psiholozi, generalno psiholingvisti. Istraživanje na koje smo se oslonili u procesu uvođenja nastave francuskog jezika u osnovnoj školi „Vladislav Ribnikar" bilo je doktorska teza Milje Stošić ${ }^{11}$. Prikazano eksperimentalno ispitivanje sposobnosti dece za učenje stranih jezika u njihovoj sedmoj i devetoj godini života pokazalo je da razlike u njihovoj sposobnosti, ni kod dečaka niti kod devojčica, nema. Rano životno doba je pogodno za govornu veštinu ne samo zbog onoga što u metodici zovemo „fonetskim rešetom“, već i zbog trajanja samog procesa. Moram naglasiti da početkom šezdesetih godina nije bilo mnogo radova ovog tipa, mnogo više smo mogli da čitamo razne deskripcije o individualnom usvajanju jezika dece koje su svaka na svoj način izlagale pojedinačna iskustva, ali nisu davale nama potrebne odgovore. Tek kasniji radovi psiholingvista koji su pratili razvoj dečijeg govora, ukazali su da su psihičke i saznajne sposobnosti u populaciji mladih učenika maternjeg ili stranog jezika više izražene kao individualno svojstvo, dok odrasli učenici više reaguju kao grupa (ili grupe) unutar celine. Ta celina u našim prilikama je razred, i ta njihova osobina se ispoljava tako što često imamo jednu trećinu tj jednu grupu dobrih učenika, drugu srednje dobrih, treću nedovoljno dobrih. I to tako ostaje skoro tokom celog perioda učenja. Suprotno tome, mladi učenik je individua za sebe: on je govorljiv ili ćutljiv, željan da se istakne ili je u izvesnoj meri nezainteresovan, prepoznaje lako značenja koja su slikovito ili simbolima predstavljena, voli da peva ili voli da crta, ima posebno izražen smisao za imitaciju, te voli da glumi, podražava govor njemu simpatičnih osoba, a najćešće podražava specifično

11 Stošić Milja, Početak učenja stranih jezika kod dece kao pedagoški problem, doktorska teza, Filozofski fakultet, Beograd, 1962. 338 str. 
NAŠE ISKUSTVO O RANOJ NASTAVI STRANOG JEZIKA U ŠKOLSKOM SISTEMU

izražavanje svojih nastavnika. Deca su po prirodi veoma različita, to ne treba dokazivati, ali ne treba dokazivati ni to da je sklonost ka igri njihova zajednička osobina. A igra podrazumeva i pokret i glas, i kontakt sa bliskim osobama ili drugovima. U igri se oslobađaju sve one potisnute sklonosti koje omogućuju da se učenici zbliže, da uživaju u zajedničkom događaju, pa i kad govore nekako drugačije, nekim jezikom koji često ne znaju ni kako se zove ali to čak nije ni važno, to ih zabavlja, jer je sve drugačije, kao neka nestvarnost. A ta nestvarnost, polako, iz časa u čas, postaje stvarnost. Neki učenici do tog saznanja stignu brže, drugi sporije. I ne samo to. Svaki element iz saznajnog procesa usvaja se drugačijim tempom. Drugim rečima, recepcija bilo kog elementa jezika realizovaće se u različitim trenucima. Najveći broj učenika će odgovarati na zahteve nastavnika svesno ili nesvesno, više ili manje tačno, odmah. Drugi će se postepeno privikavati, gledati i slušati. Komunikaciju s njima ćemo kasnije uspostaviti.

Ima i takvih koji će pokazati svoje sposobnosti tek kada im umesto slike, koja je oslonac razumevanju, ponudimo pisani tekst. Taj individualni momenat osvešćivanja da glasovi koje izgovara, reči i rečenice koje je naučio u nekoj igri imaju i neku drugu svrhu van igre, ozbiljniju i korisniju, taj momenat će biti onaj kada dete počinje da uči, a ne samo da se igra.

\section{Kako deca uče jezik}

Sva deca sveta počinju svoj govorni razvitak tako što izgovaraju veliki broj najrazličitijih glasova, ali ih vremenom svode na one glasove koje čuju u svom okruženju. Okruženi tetkama, mamama, bakama i strinama ona slušaju njihove milopojke, ponekad zahteve, pa pohvale itd. i u toj polifoniji vremenom prepoznaju glasove tih reči koje slažu preko svojih receptora u svoj mali misaoni fond, a onda ih, po svom nagonu, reprodukuju kako mogu i umeju. Često nije lako prepoznati šta žele da kažu, ali to nije njihova greška, to je nedostatak naše sposobnosti da prepoznamo dečiji govor. Učenici na ranom uzrastu uče da govore strani jezik po istom sistemu kao 
što uče maternji jezik. Međutim, u procesu učenja stranog jezika, bilo na predškolskom uzrasti ili u školskim uslovima, ona sporije dosežu do stepena recepcije i produkcije. Razlog tome je nedovoljno posvećeno vreme ovom nastavnom predmetu ${ }^{12}$, tj. onome što se na francuskom zove bain linguistique, ili još jasnije, nedostaju mu sve te tete i strine, mame i babe koje mu pričaju o njegovoj lepoti i dobroti. Činjenica je da klasične metode razredne nastave nikako ne odgovaraju metodama koje daju rezultate u nastavi stranog jezika u početnim razredima. Jedina metoda njima dostupna je ona koja je prilagođena njihovoj psihi i njihovim navikama. Poznajete li dete koje je učilo da govori jezik svoje majke prateći tekst u knjizi, dete koje sedi mirno, sluša šta mu se govori, ponavlja, odgovara zahtevima? Ne, ali poznajete svakako decu koja su na osnovu igara, recitacija i pesama, glume, imitiranja ili naslikanih prikaza naučila mnoge pojmove. Stvarnost koja ih okružuje njima služi kao podloga u učenju i zamena je za papirnati tekst kojim se odrasli učenici potpomažu. Međutim, škola, učionice i klupe, isparcelisani prostor, vremenska ograničenost časa, učenici skučeni na svojim sedištima i pritisnuti nametnutom disciplinom, to nije pogodan ambijent za učenje jezika na ovom uzrastu. Ako ispravno mislim, didaktički postupak, odnosno primena metoda u nastavnom procesu na ranom uzrastu u međuodnosu je sa fizičkim ambijentom u kojem se primenjuje. Jedan od osnovnih uslova koje škola treba da ispuni jeste kreiranje okruženja u kojem se odvija nastava. Svaki nastavnik zna šta se pod tim podrazumeva: mogućnost da se na času realizuje sve što je predviđeno u nastavnom postupku. U današnjim školama učionice ili kabineti pružaju mnogo bolje uslove za uspešan rad. U vreme našeg eksperimenta toga skoro da nije bilo. Ipak, mi smo taj strogo uređen prostor učionice svakodnevno pretvarali u drugu prostoriju: ponedeljkom je to bila sala za izložbu u kojoj su bile izlagane figurine u raznim odnosima predstavljajući situacije i dijaloge predviđene za obradu. Utorkom je učionica bila pozornica, na kojoj su učenici glumili sekvence iz naučenih dijaloga, modifikujući ih po

12 Najčešće se na početnom nivou učenja posvećuju dva časa nedeljno, dok je tokom eksperimenta Prosvetno-pedagoškog zavoda nastava bila organizovana tokom cele radne nedelje po jedan čas. 
NAŠE ISKUSTVO O RANOJ NASTAVI STRANOG JEZIKA U ŠKOLSKOM SISTEMU

svojoj volji. Naravno da je tu bilo i recitacija i pesama i prilagođenih igara. Sredom smo napuštali učionicu, u savršenoj tišini odlazili u fiskulturnu salu. To su bili najlepši trenuci, igrali smo organizovane igre, verali se po gimnastičkim spravama. Četvrtak je bio posvećen prikazivanju francuskih regiona i spomenika, nekih poznatih detalja vezanih za francusko društvo s ciljem da učenici zapamte nazive spomenika, mesta gde se nalaze, a često i neke datume. Petkom smo učionicu pretvarali u slikarski atelje. Crtanje na listovima bloka broj 5 , bojenje vodenim bojicama! Imali su dopuštenje da slobodno izlaze do toaleta da bi menjali vodu, prali četkice i ruke, često i lice jer su obično bili izmazani svim bojama, prljavi ali prezadovoljni. Subota je bila njihov dan. Sve im je bilo dozvoljeno, pod uslovom da međusobno govore francuskim jezikom. Mogli su čak i da imitiraju svoje nastavnike. Ovakav način nastave nije se mogao odvijati u okolnostima klasične discipline. Komoditet koji su osećali dozvolom da sede gde hoće i s kim hoće, da menjaju mesto, da pitaju ili pričaju šta se desilo ili dešava u porodici ili okolini, a pritom i njihov polet da govore, ponekad svi u glas, stvarao je pomalo haotičnu situaciju koju je nastavnik morao da usmerava i da iz njih izvlači maksimalni napor da upotrebljavaju svoje znanje francuskog jezika. Jer tako neuobičajeno ponašanje koje im je bilo dozvoljeno, a koje mnoge kolege nisu odobravale, doprinosilo je da se učenici opuste, da steknu sigurnost i veru u svoje znanje, da nestane sumnja kako neko drugi više zna. Da zavlada opšte mišljenje kako svi znaju sve.

\section{Pedagoški materijal na koji smo se oslanjali}

Te 1968. godine kada smo se susreli sa učenicima, kojih je bilo i do četrdeset po jednom razredu, naš početak ličio je na čist hazard. Dogovor je bio da se srpski jezik izostavi potpuno iz komunikacije, s namerom da učenicima uskratimo mogućnost i privilegiju upotrebe svog jezika i da ih navikavamo da maksimalno razviju prepoznavanje značenja na osnovu prikazanih elemenata ili onoga što su već naučili. Što se pedagoškog materijala tiče, domaćih produkcija nije bilo, a tri metode koje su se nudile kao francuska izdanja nisu 
odgovarala. Metoda Je lis, tu lis, zasnovana je na klasičnom tekstu, metoda Bonjour Line, koja je imala sve odlike moderne AVGS metode, opterećivala bi roditelje finansijski, a metoda Frère Jacques, koju smo u kasnijim godinama rada upotrebljavali, nije bila primenljiva za početni uzrast. Ne bih umela da govorim o tome kako su se snalazili nastavnici koji su držali nastavu drugih jezika. Nama su, svima, pomagali kulturni centri dotične zemlje onim što je postojalo od pedagoškog materijala. Francuski kulturni centar nam je izlazio u susret za ostvarenje naših ideja, ali mi smo, ipak, morali sami da pripremamo nastavni materijal. Mnogo brže nego nas tri koje smo učestvovale u nastavi francuskog jezika, tu hrabrost je smogla inspektor Radmila Čulajević, koja je bila spiritus movens celog projekta, i verujem da je za to zaslužila neko odlikovanje, ukoliko se ono dodeljivalo u to vreme i prosvetnim radnicima. Na papiru veličine A4 Radmila Čulajević je kucala u dve kolone, što je kasnije svaka od nas takođe radila, na pisaćoj mašini marke Biser, u četiri primerka pripreme za časove koje smo imali tokom jedne nedelje. U koloni s leve strane bilo je priloženo gradivo koje je nastavnik predavao, propraćeno objašnjenjima u vezi sa primenjenim postupkom. U koloni s desne strane, zavisno od toga da li se učenicima predstavlja novo gradivo ili obnavlja ono što bi trebalo da znaju, dati su pretpostavljeni odgovori, moguće greške, naročito fonetske greške i mogućnosti korekcije. Tok časa je bio prikazan u više segmenata, uvek kratkih, koji su se smenjivali i održavali dinamiku časa i pažnju učenika. Radi idealnog konsenzusa, pripreme koje su trajale cele prve i druge nastavne godine, ukupno oko 400 časova, komentarisale smo na redovnim sastancima četvrtkom u tri sata u Prosvetno-pedagoškom zavodu. A kada bi ti tekstovi prošli kroz nastavu, sumirale smo utiske o tome kako su učenici prihvatali novo gradivo, da li su shvatili značenje pojedinih sekvenci, menjali smo često način tumačenja nekih pojmova, neke smo sasvim izbacivali, ujednačavali smo pristupe, jednom rečju činili sve da gradivo prilagodimo učenicima. I to je tako išlo sve do trećeg razreda kada smo ispred učenika stavili udžbenik Frère Jacques. Bilo je pravo vreme da se njihovoj radoznalosti ponudi nešto novo: jezik na papiru. Ali s tom jezičkom formom, promenila se i forma našeg učenja. 
NAŠE ISKUSTVO O RANOJ NASTAVI STRANOG JEZIKA U ŠKOLSKOM SISTEMU

\section{Za kraj nekoliko konstatacija umesto zaključka}

Sećanje na segment moga nastavnog iskustva o kojem sam ovde govorila staro je još malo pa pola veka. Sećanja kolega koji su učestvovali u ovom projektu bila bi značajna za uobličavanje jednog potpunijeg dokumenta o počecima nastave stranih jezika na ranom uzrastu u našoj sredini. Arhivska dokumenta koja su potekla iz Prosvetno-pedagoškog zavoda, zaturena su negde. Beleške koje su mi pomogle jedino su one koje se nalaze u mojim starim agendama. Radoznalost me je odvukla na postojeće sajtove o ranom učenju stranih jezika. Moguće je da nisam našla tamo sve što je napisano u nekim bližim godinama. Ali, ono što sam našla uverava me u nepobitnu činjenicu, a to je da smo bili na dobrom putu. U ovo naše vreme opšti je konsenzus da strani jezik treba učiti na ranom uzrastu. $\mathrm{U}$ tom smislu treba delati.

Deca ranog uzrasta mogu da uče bilo koji strani jezik, na tom putu nema nikakvih smetnji, pa im samim tim nije teško.

Mladi učenici doživljavaju učenje stranog jezika kao igru, a svako dete je motivisano da se druži radi igre i u toj aktivnosti ona su sva podjednako uspešna. Jedino je, u našem slučaju, potrebno da igra bude smisleno organizovana.

U verbo-tonalnoj metodi naučili smo da se pri susretu sa nepoznatim jezikom naše uvo ponaša kao uvo gluvog čoveka. To je sigurno tačno i to je velika prepreka za učenje stranog jezika. Međutim, dete u ranom uzrastu nema tu prepreku, njegovi receptorni organi prepoznaju glasove tuđe njegovom maternjem jeziku i reprodukcija je time olakšana. Zato dete izgovara strane glasove onoliko korektno koliko i glasove maternjeg jezika, a fiksira ih postepeno sve dok ih ne smesti na određenu tačku artikulacije.

Tokom nastave stranog jezika koja obuhvata više školskih godina sa malim fondom časova, kako je to u našim školama, te liči na jedan rastegnut proces koji gubi u intenzitetu, dešava se da učenici izgube motivaciju. Mi tada govorimo o nezainteresovanosti učenika, što je retko tačno. Nezainteresovanost i nemotivisanost nemaju isto značenje.

Malo je slučajeva neuspešnih učenika u nastavi jezika na ranom uzrastu. Možemo pretpostaviti da naši učenici neće svi postići po- 
djednak uspeh, ali razlike u veštini izražavanja maternjim jezikom vidljive su na svim uzrastima. Dostignuća učenika u stranom jeziku ne mogu se upoređivati zbog individualnih osobina samih učenika i trajanja samog procesa učenja. Zato se evaluacija može posmatrati samo kao individualni uspeh, a numeričko ocenjivanje kao administrativna besmislica.

\title{
Dušanka Točanac
}

\section{NOTRE EXPÉRIENCE DE L'ENSEIGNEMENT PRÉCOCE D'UNE LANGUE ÉTRANGÈRE AUX ÉCOLIERS}

\begin{abstract}
Résumé
La langue étrangère comme matière d'enseignement dans les classes de l'école élémentaire dans le curriculum scolaire en Serbie date depuis les années soixante du $20 \mathrm{e}$ siècle. L'apprentissage d'une autre langue en plus de la langue maternelle, dès l'entrée dans le système scolaire, a été graduellement introduit. En effet, en 1966 il n'y avait qu'une seule école où on enseignait le français aux écoliers débutants, alors qu'en 1968 le nombre a augmenté - douze écoles pour quatre langues : anglais, français, allemand, russe, pour finir par couvrir la totalité des écoles en 2004. C'est cette initiative administrative et pédagogique qu'on évoque dans cet exposé.
\end{abstract}

Mot clés: la langue française, l'apprentissage/ l'enseignement précoce, l'école élémentaire Vladislav Ribnikar. 